\title{
Blood pressure decrease in spontaneously hypertensive rats folowing renal denervation or dopamine $\beta$-hydroxylase inhibition with etamicastat
}

\author{
Nuno Miguel Pires ${ }^{1}$, Bruno Igreja ${ }^{1}$, Eduardo Moura ${ }^{1}$, Lyndon Christopher Wright ${ }^{1}$, Maria Paula Serrão $0^{2,3}$ and \\ Patrício Soares-da-Silva ${ }^{1,2,3}$
}

Overactivity of the sympathetic nervous system has an important role in the development and progression of arterial hypertension. Catheter-based renal nerve ablation for the treatment of drug-resistant hypertension has recently been developed. An alternative strategy for the modulation of sympathetic nerve function is to reduce the biosynthesis of noradrenaline (NA) by inhibiting dopamine $\beta$-hydroxylase $(D \beta H)$, the enzyme that catalyzes the conversion of dopamine (DA) to NA in the sympathetic nerves. Renal denervation (RDN) surgery was performed in spontaneously hypertensive rats (SHR) to evaluate the effect of RDN on the DA and NA levels and on blood pressure over a 28-day period. The selective peripheral D $\beta \mathrm{H}$ inhibitor etamicastat (30 $\mathrm{mg} \mathrm{kg}^{-1}$ day $^{-1}$ ) was administered to another cohort of SHR. RDN and etamicastat treatment had no effect on the renal function, as assessed by measuring the water balance response, renal function and urinary electrolyte levels. RDN significantly decreased the systolic blood pressure (SBP) and the diastolic blood pressure (DBP). A gradual return of the SBP and the DBP to the high baseline levels was observed over time. Conversely, treatment with etamicastat resulted in a significant decrease in the SBP and the DBP at all time points. On the last day of the assessment, NA levels in renal tissue were significantly decreased in both RDN and etamicastat-treated groups. In contrast, the NA levels in the left ventricle were decreased only in the etamicastattreated group. Thus, RDN produces transitory decreases in blood pressure, whereas prolonged downregulation of sympathetic drive with the $D \beta H$ inhibitor etamicastat results in a sustained decrease in the SBP and the DBP.

Hypertension Research (2015) 38, 605-612; doi:10.1038/hr.2015.50; published online 9 April 2015

Keywords: renal denervation; dopamine $\beta$-hydroxylase inhibition; sympathetic nervous system; spontaneously hypertensive rat

\section{INTRODUCTION}

Hypertension is one of the most prevalent cardiovascular risk factors. ${ }^{1}$ Overall, $26.4 \%$ of the adult population in 2000 had hypertension, and the number of adults with hypertension is predicted to increase by $\sim 60 \%$ to a total of 1.6 billion in $2025 .^{2}$ Despite the use of generally effective antihypertensive therapy, blood pressure (BP) often remains above target levels because of poor adherence, an inadequate treatment regimen and/or treatment resistance. ${ }^{3}$ Resistant hypertension is currently defined as the failure to achieve a goal of $\mathrm{BP}<140 / 90 \mathrm{~mm} \mathrm{Hg}$ in patients who are compliant with the maximal tolerated doses of a minimum of three antihypertensive drugs, one of which is a diuretic. The prevalence of resistant hypertension is unknown, but clinical trials suggest that it is not rare and may involve perhaps $20-30 \%$ of the study participants. ${ }^{4}$

The activation of the sympathetic nervous system, which involves an increased spillover of noradrenaline (NA) in specific organs such as the heart and kidney, has a major role in the pathophysiology of hypertension $^{5-7}$ and congestive heart failure $e^{8,9}$ and is associated with an increased mortality. ${ }^{10-12}$ Recently, catheter-based renal nerve ablation has been developed for the treatment of drug-resistant hypertension. ${ }^{13-17}$ Most of these systems direct a radiofrequency energy along the lengths of the main renal arteries to ablate the renal sympathetic nerves that lie within and just beyond the adventitia. ${ }^{18}$ Catheter-based renal nerve ablation results in a sustained reduction of BP that can still be observed 3 years post denervation. ${ }^{19}$ Nonetheless, the first prospective, single-blind, randomized, sham-controlled trial showed no difference in office or 24-hour ambulatory BP at 6 months between the renal denervation ( $\mathrm{RDN}$ ) and sham procedure groups. ${ }^{20}$ Moreover, limitations to the procedure exist, including patient eligibility criteria. The patients who are eligible based on criteria used in published studies represent an exceedingly small proportion of the total hypertensive population; such criteria thus prevent the use of $\mathrm{RDN}$ in a broader range of hypertensive patients. ${ }^{21}$

Therefore, alternative strategies to modulate sympathetic nerve function are attractive. Among such alternative strategies, the inhibition of dopamine $\beta$-hydroxylase $(\mathrm{D} \beta \mathrm{H})$, which is the enzyme

${ }^{1}$ Department of Research \& Development, BIAL-Portela \& Ca, S.A., S. Mamede do Coronado, Portugal; ${ }^{2}$ Department of Pharmacology \& Therapeutics, Faculty of Medicine, University of Porto, Porto, Portugal and ${ }^{3}$ MedlnUP - Center for Drug Discovery and Innovative Medicines, University of Porto, Porto, Portugal

Correspondence: Professor P Soares-da-Silva, Department of Research \& Development, BIAL-Portela \& Ca, Av. da Siderurgia Nacional, S. Mamede do Coronado 4745-457, Portugal.

E-mail: psoares.silva@bial.com

Received 13 October 2014; revised 1 February 2015; accepted 20 February 2015; published online 9 April 2015 


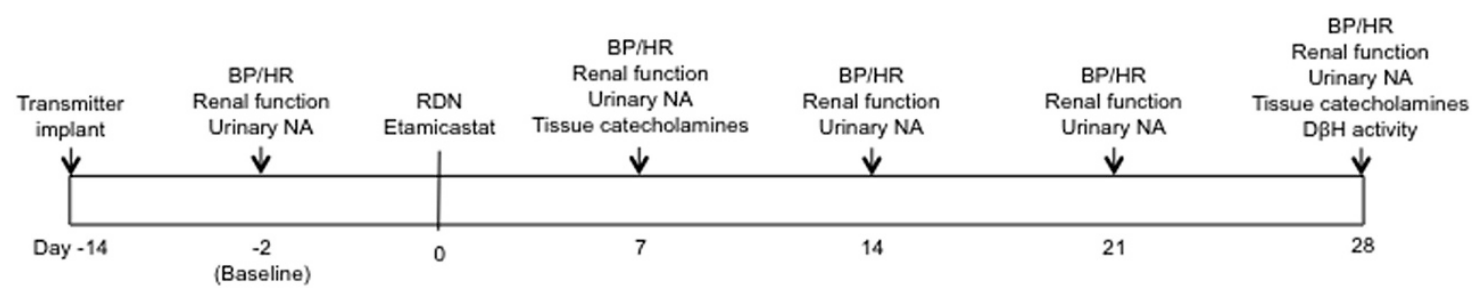

Figure 1 Timeline of the experimental protocol. $\mathrm{D} \beta \mathrm{H}$, dopamine $\beta$-hydroxylase; HR, heart rate; $\mathrm{BP}$, blood pressure; NA, noradrenaline; RDN, renal denervation.

responsible for the conversion of dopamine (DA) to NA in sympathetic nerves, has emerged as the most promising. ${ }^{22} \mathrm{D} \beta \mathrm{H}$ inhibition has the potential to cause a gradual sympathetic slowdown instead of an acute inhibition, as is caused by $\beta$-blockers, thereby reducing the negative hemodynamic impacts. ${ }^{23} \mathrm{D} \beta \mathrm{H}$ inhibition also increases the availability of $\mathrm{DA},{ }^{24,25}$ which improves renal function by causing renal vasodilatation and inducing diuresis and natriuresis. ${ }^{26-28}$ Several $\mathrm{D} \beta \mathrm{H}$ inhibitors have been reported, ${ }^{29-31}$ but none have yet achieved the marketing approval because of their low potency, poor $\mathrm{D} \beta \mathrm{H}$ selectivity $^{32}$ and/or significant adverse effects. ${ }^{33}$ Etamicastat (also known as BIA 5-453; (R)-5-(2-aminoethyl)-1-(6,8-difluorochroman3-yl)-1,3-dihydroimidazole-2-thione hydrochloride) is a newgeneration $\mathrm{D} \beta \mathrm{H}$ inhibitor in development by BIAL-Portela \& $\mathrm{C}^{\mathrm{a}}$, S.A. (S. Mamede do Coronado, Portugal) as a potential new drug therapy for cardiovascular disorders. Etamicastat is a reversible $\mathrm{D} \beta \mathrm{H}$ inhibitor that has limited access to the brain and acts mainly on the periphery by decreasing NA levels in the sympathetically innervated tissues. $^{34,35}$ Etamicastat has been shown to reduce both systolic BP (SBP) and diastolic BP (DBP), when administered alone or in combination with other antihypertensive drugs, and to reduce urinary NA excretion in spontaneously hypertensive rats (SHR); no changes in $\mathrm{BP}$ have been reported in normotensive Wistar-Kyoto rats. ${ }^{36,37}$ Recently, etamicastat has been shown to have BP-lowering effects in hypertensive patients. ${ }^{38}$

The present study was designed to compare the efficacy of RDN and $\mathrm{D} \beta \mathrm{H}$ inhibition by etamicastat in the reduction of peripheral sympathetic activity and the amelioration of high BP in SHR.

\section{METHODS}

\section{Animals and general procedures}

Male 12-week-old SHR (Charles River Laboratories, Domaine des Oncins, France) were housed in Macrolon cages with free access to food and tap water under controlled environmental conditions in a colony room (12 hours lightdark cycle, room temperature $22 \pm 1^{\circ} \mathrm{C}$ and humidity $55 \pm 15 \%$ ). All animal procedures conformed to the guidelines in Directive 2010/63/EU of the European Parliament concerning the protection of animals used for scientific purposes and to the Portuguese law on animal welfare (Decreto-Lei 113/2013). Etamicastat was synthesized in the Laboratory of Chemistry of BIAL-Portela \& C, S.A. All other chemicals and materials were obtained from Sigma-Aldrich (St Louis, MO, USA), unless noted otherwise. For all surgeries, rats were anesthetized with pentobarbital sodium $\left(50 \mathrm{mg} \mathrm{kg}^{-1} \mathrm{IP}\right)$. Gentamicin sulfate $\left(10 \mathrm{mg} \mathrm{kg}^{-1} \mathrm{IM}\right.$; Pfizer, New York, NY, USA) was administered before the surgery. Carprofen ( $5 \mathrm{mg} \mathrm{kg}^{-1} \mathrm{SC}$; Pfizer) was given twice daily for 2 days post surgery.

\section{Experimental protocol}

The timeline for the experimental protocol is shown in Figure 1. SHR were instrumented with radio telemeters (TA11PA-C40, DSI, St Paul, MN, USA) as previously described. ${ }^{36}$ Rats were allowed to recover individually for 2 weeks before sympathetic nervous system modulation. Animals were randomly assigned to the control $(n=7), \operatorname{RDN}(n=6)$ or etamicastat $(n=6)$ treatment groups. An additional, satellite group of animals was used to evaluate tissue catecholamines 7 days post intervention (control group, $n=6$; RDN group, $n=5$; etamicastat treatment group, $n=6$ ).

\section{Renal denervation}

RDN surgery was performed as previously described. ${ }^{39}$ Briefly, a lateral incision was made on each side of the abdominal wall to expose the renal arteries and veins of each kidney. Under a dissecting microscope, visible renal nerves, fat and connective tissue were stripped from the renal vessels. Renal vessels were then painted with $10 \%$ phenol in $96 \%$ ethanol to ensure the destruction of any remaining nerves.

\section{Chronic treatment with etamicastat}

Rats were administered $30 \mathrm{mg} \mathrm{kg}^{-1}$ day $^{-1}$ body weight of etamicastat in drinking water. The daily dose of etamicastat attained for the 7-days period (for the satellite tissue catecholamine-measurement experiments) was $31.9 \pm 2.4 \mathrm{mg} \mathrm{kg}^{-1}$ body weight and for the 28-days period (all other experiments) was $30.2 \pm 1.7 \mathrm{mg} \mathrm{kg}^{-1}$ body weight.

\section{Evaluation of renal function}

Rats were placed in individual metabolic cages (Tecniplast, Varese, Italy), and 24-hour urine samples were collected before (baseline) and 7, 14, 21 and 28 days after the start of the protocol. All biochemical assays were performed by using a Cobas Mira Plus analyzer (ABX Diagnostics for Cobas Mira, Geneva, Switzerland).

\section{Cardiovascular evaluation}

SBP, DBP, mean arterial pressure (MAP) and heart rate (HR) telemetry recordings were recorded before (baseline) and 7, 14, 21 and 28 days post sympatholytic treatment. The data were collected for $40 \mathrm{~s}$ every $10 \mathrm{~min}$ and averaged over 48 hours by using the Dataquest A.R.T. acquisition and analysis system 4.0 (DSI).

\section{Pharmacokinetic evaluation}

Pharmacokinetic evaluation was performed after the completion of the experimental protocol. Blood was collected from the vena cava (S-Monovette, Sarstedt, Nümbrecht, Germany), and plasma etamicastat levels were quantified by a tandem mass spectrometer as previously described. ${ }^{40}$

\section{Catecholamine assay}

NA and DA levels were quantified in the frontal cortex, kidney cortex, left ventricle of the heart and vas deferens on days 7 and 28 of the protocol. Catecholamine (DA, NA and adrenaline) content was assessed in right adrenal gland samples. Twenty-four-hour urine samples from rats housed individually in metabolic cages (Tecniplast) were collected for NA quantification before (baseline) and 7, 14, 21 and 28 days after the start of the protocol. Samples were analyzed by using a high performance liquid chromatography system with electrochemical detection as previously described. ${ }^{41}$

\section{Measurement of $\mathrm{D} \beta \mathrm{H}$ activity}

Determination of $\mathrm{D} \beta \mathrm{H}$ activity was performed according to the method of Nagatsu and Udenfriend ${ }^{42}$, with some modifications. In brief, on the final day of the protocol, left adrenal glands were removed, placed in $200 \mu \mathrm{l}$ of $50 \mathrm{~mm}$ Tris, pH 7.4 and stored at $-80^{\circ} \mathrm{C}$ until analysis. Samples were thawed on ice 
and homogenized (Precellys bead beater, Bertin Technologies, Montigny-leBretonneux, France) for two cycles per $5 \mathrm{~s}$ at 5000 r.p.m., after which the total protein content in the homogenates was quantified (Bradford reagent, Bio-Rad, Hercules, CA, USA). Samples were diluted to $1.5 \mathrm{mg} \mathrm{ml}^{-1}$ and mixed with $700 \mu \mathrm{l}$ of incubation buffer $(18.0 \mathrm{ml}$ of $1 \mathrm{M}$ sodium acetate, $\mathrm{pH} 5 ; 4.5 \mathrm{ml}$ of $0.2 \mathrm{M}$ sodium fumarate; $4.5 \mathrm{ml}$ of $0.2 \mathrm{M}$ ascorbic acid; $4.5 \mathrm{ml}$ of $0.02 \mathrm{M}$ pargyline; $13.5 \mathrm{ml}$ of $0.2 \mathrm{M} \mathrm{N}$-ethylmaleimide; $9.0 \mathrm{ml}$ of catalase, $14200 \mathrm{U} \mathrm{ml}^{-1} ; 4.5 \mathrm{ml}$ of Milli-Q water (Milli-Q Advantage A10 Ultrapure Water Purification System, Merck Millipore, Darmstadt, Germany); $4.5 \mathrm{ml}$ of $20 \mu \mathrm{m}$ copper (II) sulfate). The enzymatic reaction was initiated at $37^{\circ} \mathrm{C}$ with $50 \mu \mathrm{l}$ of $0.5 \mathrm{M}$ tyramine. After $45 \mathrm{~min}$, the reaction was stopped with $200 \mu \mathrm{l}$ of $2 \mathrm{M}$ perchloric acid. Samples were then centrifuged for $5 \mathrm{~min}$ at $9000 \mathrm{~g}$ to pellet the protein, and $800 \mu \mathrm{l}$ of the supernatant was transferred into SPE cartridges (Isolute SCX-3, $100 \mathrm{mg}$ fixedwell plate, Biotage, Uppsala, Sweden). Samples were eluted with $600 \mu \mathrm{l}$ of $4 \mathrm{M}$ ammonium hydroxide and then derivatized with $200 \mu \mathrm{l}$ of $2 \%$ sodium periodate; after $6 \mathrm{~min}$, the reaction was stopped with $200 \mu \mathrm{l}$ of $10 \%$ sodium metabisulfite. An amount of $200 \mu \mathrm{l}$ of the derivatized samples was then transferred to a 96-well plate, and absorption was measured by spectrophotometry at $330 \mathrm{~nm}$ (Spectramax Plus, Molecular Devices, Silicon Valley, CA, USA). D $\beta H$ activity was assessed by measuring the quantity of octopamine formed (expressed in $\mathrm{ng} \mathrm{mg}^{-1}$ of protein per min). ${ }^{43}$

\section{Statistical analysis}

The data are presented as the mean \pm s.e.m.. Data analyses were performed using Prism 6 (GraphPad Software, San Diego, CA, USA). The data for the experimental group were compared to those of the control group using oneway or repeated-measures analysis of variances followed by Dunnett's multiple comparison tests. A value of $P<0.05$ was considered to be statistically significant.

\section{RESULTS}

Fluid balance and renal function responses to peripheral sympathetic modulation

Water intake, urine output and renal function were assessed at baseline and 7, 14, 21 and 28 days post sympatholytic therapy. RDN had no significant effect on fluid balance. Prolonged etamicastat

Table 1 Body weight and water balance response after renal denervation or etamicastat treatment in the SHR

\begin{tabular}{|c|c|c|c|}
\hline & Control & Renal denervation & Etamicastat \\
\hline \multicolumn{4}{|c|}{ Body weight (g) } \\
\hline Baseline & $361.9 \pm 8.7$ & $369.0 \pm 5.7$ & $365.3 \pm 7.3$ \\
\hline 7 days & $371.7 \pm 9.6$ & $358.0 \pm 10.3$ & $376.0 \pm 8.2$ \\
\hline 14 days & $376.9 \pm 9.8$ & $365.5 \pm 11.1$ & $380.8 \pm 8.6$ \\
\hline 21 days & $380.1 \pm 10.0$ & $383.3 \pm 10.8$ & $384.0 \pm 8.1$ \\
\hline 28 days & $382.0 \pm 9.8$ & $389.2 \pm 11.0$ & $387.0 \pm 8.6$ \\
\hline \multicolumn{4}{|c|}{ Water intake ( $\mathrm{ml}$ per $24 \mathrm{~h})$} \\
\hline Baseline & $19.3 \pm 1.3$ & $12.9 \pm 1.2^{*}$ & $20.3 \pm 1.5$ \\
\hline 7 days & $20.5 \pm 2.1$ & $17.1 \pm 1.0$ & $13.4 \pm 1.4^{*}$ \\
\hline 14 days & $17.4 \pm 1.7$ & $14.4 \pm 0.9$ & $11.7 \pm 1.1^{*}$ \\
\hline 21 days & $17.4 \pm 2.1$ & $11.5 \pm 1.2^{*}$ & $10.7 \pm 0.7^{*}$ \\
\hline 28 days & $16.1 \pm 2.0$ & $16.4 \pm 0.9$ & $8.6 \pm 0.9 *$ \\
\hline \multicolumn{4}{|c|}{ Urine output ( $\mathrm{ml}$ per $24 \mathrm{~h}$ ) } \\
\hline Baseline & $7.6 \pm 1.4$ & $6.6 \pm 1.3$ & $8.5 \pm 1.0$ \\
\hline 7 days & $8.0 \pm 2.2$ & $6.9 \pm 1.0$ & $3.3 \pm 0.6$ \\
\hline 14 days & $8.8 \pm 1.4$ & $6.3 \pm 0.8$ & $4.1 \pm 0.5^{*}$ \\
\hline 21 days & $8.8 \pm 1.8$ & $6.9 \pm 0.6$ & $2.9 \pm 0.2^{*}$ \\
\hline 28 days & $9.3 \pm 1.2$ & $7.2 \pm 0.5$ & $4.4 \pm 0.4^{*}$ \\
\hline
\end{tabular}

Abbreviation: SHR, spontaneously hypertensive rats.

Mean \pm s.e.m., $n=6-7$ per group.

${ }^{*} P<0.05$ vs control group. One-way analysis of variance followed by Dunnett's multiple comparison test. treatment $\left(30 \mathrm{mg} \mathrm{kg}^{-1}\right.$ day $\left.^{-1}\right)$ decreased the water intake and urinary output (Table 1). No global changes in fluid balance were observed. Observations from our laboratory showed that decreased water intake may be related to palatability (unpublished data). Etamicastat was found in the plasma of all animals. The concentrations of etamicastat in plasma were $145.8 \pm 21.2 \mathrm{ng} \mathrm{ml}^{-1}$ (satellite) and $154.5 \pm 25.8 \mathrm{ng} \mathrm{ml}^{-1}$ (28-day period). Renal function was unaffected by RDN or etamicastat treatment (Tables 2 and 3 ).

Cardiovascular responses to peripheral sympathetic modulation As shown in Figures $2 \mathrm{a}-\mathrm{c}$, the control group of SHR had established hypertension, and no difference in SBP, DBP or MAP compared with baseline values occurred throughout the protocol $(\mathrm{SBP}=178.6 \pm 1.0, \quad \mathrm{DBP}=129.0 \pm 2.3, \quad \mathrm{MAP}=153.3 \pm 1.4 \mathrm{~mm} \mathrm{Hg})$. The baseline BP was similar between groups. In RDN-treated animals, SBP, DBP and MAP values were significantly $(P<0.05)$ decreased on days 7 and 14 post denervation compared with the baseline. By day 21, the BP values were no longer significantly different from baseline values or the corresponding values in control animals. SBP, DBP and MAP returned to baseline values on the final day of the assessment (day 28 after targeted sympathetic ablation; $\mathrm{SBP}=178.1 \pm 10.5$, $\mathrm{DBP}=125.1 \pm 10.1, \mathrm{MAP}=150.7 \pm 10.1 \mathrm{~mm} \mathrm{Hg}$ ). In contrast, peripheral sympathetic modulation by etamicastat induced a sustained BP decrease throughout the entire 28-days period.

The effects of sympathetic modulation on HR are depicted in Figure $2 \mathrm{~d}$. The baseline pulse rate was similar between the groups. The HR of control SHR fell transiently from the baseline $(314.2 \pm 2.9$ beats per min) on days 14 and 28 ( -9 beats per min at both time points). After RDN surgery, rats' HRs were not different from baseline $(310.0 \pm 3.4$ beats per min) 7 days post surgery but were significantly increased 14 days after $\mathrm{RDN}$ ( +14 beats per min), after which they returned to baseline values by days 21 and 28 of the assessment. Prolonged etamicastat treatment in the drinking water caused a small,

Table 2 Renal function after renal denervation or etamicastat treatment in the SHR

\begin{tabular}{|c|c|c|c|}
\hline & Control & Renal denervation & Etamicastat \\
\hline \multicolumn{4}{|c|}{ Urinary protein (mg per $24 \mathrm{~h}$ ) } \\
\hline Baseline & $10.6 \pm 0.8$ & $11.2 \pm 1.1$ & $16.1 \pm 2.9$ \\
\hline 7 days & $10.1 \pm 0.7$ & $10.3 \pm 1.8$ & $10.9 \pm 3.3$ \\
\hline 14 days & $11.3 \pm 0.8$ & $8.4 \pm 1.3$ & $10.0 \pm 2.2$ \\
\hline 21 days & $10.0 \pm 1.2$ & $9.9 \pm 0.6$ & $9.3 \pm 2.0$ \\
\hline 28 days & $12.5 \pm 1.3$ & $10.6 \pm 0.3$ & $8.4 \pm 0.6^{*}$ \\
\hline \multicolumn{4}{|c|}{ Urinary creatinine ( $m g$ per $24 \mathrm{~h}$ ) } \\
\hline Baseline & $9.3 \pm 0.8$ & $8.7 \pm 0.5$ & $9.2 \pm 0.5$ \\
\hline 7 days & $8.3 \pm 0.6$ & $9.0 \pm 0.4$ & $7.5 \pm 0.8$ \\
\hline 14 days & $10.1 \pm 0.6$ & $8.9 \pm 0.5$ & $8.3 \pm 0.5^{*}$ \\
\hline 21 days & $8.8 \pm 0.9$ & $9.8 \pm 0.3$ & $7.4 \pm 0.3$ \\
\hline 28 days & $10.8 \pm 0.8$ & $10.1 \pm 0.6$ & $8.9 \pm 0.4$ \\
\hline \multicolumn{4}{|c|}{ Urinary urea (mg per $24 h$ ) } \\
\hline Baseline & $325.5 \pm 35.4$ & $357.9 \pm 14.8$ & $363.2 \pm 15.1$ \\
\hline 7 days & $327.7 \pm 19.7$ & $376.0 \pm 17.5$ & $304.8 \pm 35.4$ \\
\hline 14 days & $379.4 \pm 24.7$ & $337.3 \pm 17.5$ & $317.6 \pm 18.4$ \\
\hline 21 days & $343.7 \pm 42.9$ & $345.9 \pm 11.9$ & $290.8 \pm 11.0$ \\
\hline 28 days & $415.9 \pm 27.8$ & $364.9 \pm 7.5$ & $356.4 \pm 16.2$ \\
\hline
\end{tabular}

Abbreviation: SHR, spontaneously hypertensive rats.

Mean \pm s.e.m., $n=6-7$ per group.

${ }^{*} P<0.05$ vs control group. One-way analysis of variance followed by Dunnett's multiple comparison test. 
Table 3 Urinary electrolytes after renal denervation or etamicastat treatment in the SHR

\begin{tabular}{|c|c|c|c|}
\hline & Control & Renal denervation & Etamicastat \\
\hline \multicolumn{4}{|c|}{ Urinary $\mathrm{Na}^{+}(\mu \mathrm{mol}$ per $24 \mathrm{~h})$} \\
\hline Baseline & $255 \pm 33$ & $349 \pm 23$ & $530 \pm 98 *$ \\
\hline 7 days & $381 \pm 159$ & $557 \pm 88$ & $404 \pm 48$ \\
\hline 14 days & $351 \pm 84$ & $403 \pm 23$ & $266 \pm 18$ \\
\hline 21 days & $578 \pm 248$ & $531 \pm 120$ & $290 \pm 22$ \\
\hline 28 days & $698 \pm 209$ & $567 \pm 116$ & $356 \pm 41$ \\
\hline \multicolumn{4}{|c|}{ Urinary $K^{+}(\mu \mathrm{mol}$ per $24 \mathrm{~h})$} \\
\hline Baseline & $892 \pm 125$ & $803 \pm 26$ & $1021 \pm 95$ \\
\hline 7 days & $1013 \pm 133$ & $1174 \pm 130$ & $716 \pm 94$ \\
\hline 14 days & $1072 \pm 90$ & $970 \pm 108$ & $747 \pm 78^{*}$ \\
\hline 21 days & $1067 \pm 187$ & $950 \pm 67$ & $621 \pm 72$ \\
\hline 28 days & $979 \pm 88$ & $1027 \pm 113$ & $697 \pm 56$ \\
\hline \multicolumn{4}{|c|}{ Urinary $\mathrm{Cl}^{-}(\mu \mathrm{mol}$ per $24 \mathrm{~h})$} \\
\hline Baseline & $1409 \pm 200$ & $1644 \pm 137$ & $2032 \pm 341$ \\
\hline 7 days & $1729 \pm 222$ & $2432 \pm 302$ & $1507 \pm 249$ \\
\hline 14 days & $1184 \pm 162$ & $1860 \pm 189^{*}$ & $990 \pm 122$ \\
\hline 21 days & $1158 \pm 176$ & $1682 \pm 149^{*}$ & $924 \pm 41$ \\
\hline 28 days & $1698 \pm 97$ & $1470 \pm 100$ & $2160 \pm 326$ \\
\hline \multicolumn{4}{|c|}{ Urinary $\mathrm{Na}^{+}-$to- $\mathrm{K}^{+}$ratio } \\
\hline Baseline & $0.38 \pm 0.07$ & $0.41 \pm 0.04$ & $0.51 \pm 0.07$ \\
\hline 7 days & $0.54 \pm 0.19$ & $0.46 \pm 0.05$ & $0.59 \pm 0.08$ \\
\hline 14 days & $0.32 \pm 0.05$ & $0.48 \pm 0.05^{*}$ & $0.37 \pm 0.03$ \\
\hline 21 days & $0.62 \pm 0.17$ & $0.55 \pm 0.11$ & $0.50 \pm 0.07$ \\
\hline 28 days & $0.53 \pm 0.10$ & $0.58 \pm 0.14$ & $0.51 \pm 0.04$ \\
\hline
\end{tabular}

Abbreviation: SHR, spontaneously hypertensive rats.

Mean \pm s.e.m., $n=6-7$ per group.

${ }^{*} P<0.05$ vs control group. One-way analysis of variance followed by Dunnett's Multiple Comparison Test.

but significant, decrease in HR throughout the protocol (baseline: $311.8 \pm 3.5,7$ days: $295.3 \pm 2.0,14$ days: $284.4 \pm 0.7,21$ days: $287.6 \pm 1.9$ and 28 days: $287.2 \pm 2.8$ beats per min).

\section{Catecholamine content in tissues}

NA and DA tissue levels were assayed on days 7 and 28 of the protocol. As depicted in Figures 3a and c, RDN resulted in a sustained and marked depletion $(\approx 95 \%$ decrease $)$ of NA levels in the renal cortex of both the left and right kidneys compared with control SHR. No effects on NA levels in the frontal cortex or vas deferens were observed, but there was a transient 1.5-fold increase in NA content in the left ventricle of the heart on day 7 of the protocol. On the other hand, sympathetic modulation via treatment with etamicastat resulted in a prolonged, $\approx 50 \%$ decrease in NA content in all peripheral tissues 7 and 28 days post intervention. No differences in tissue DA levels were observed after RDN surgery. In contrast, prolonged etamicastat treatment resulted in a significant 3-15-fold increase in DA content in all peripheral tissues compared with controls throughout the protocol (Figures $3 \mathrm{~b}$ and $\mathrm{d}$ ).

As shown in Figure 4, DA levels in the adrenal glands were significantly increased after etamicastat treatment on days 7 ( $\approx 17$-fold increase) and 28 ( $\approx 18$-fold increase) of the protocol. No difference in the DA content of the adrenal glands was observed after RDN. Targeted RDN significantly increased NA (1.4-fold increase) and adrenaline (1.3-fold increase) levels in the adrenal glands 7 days post
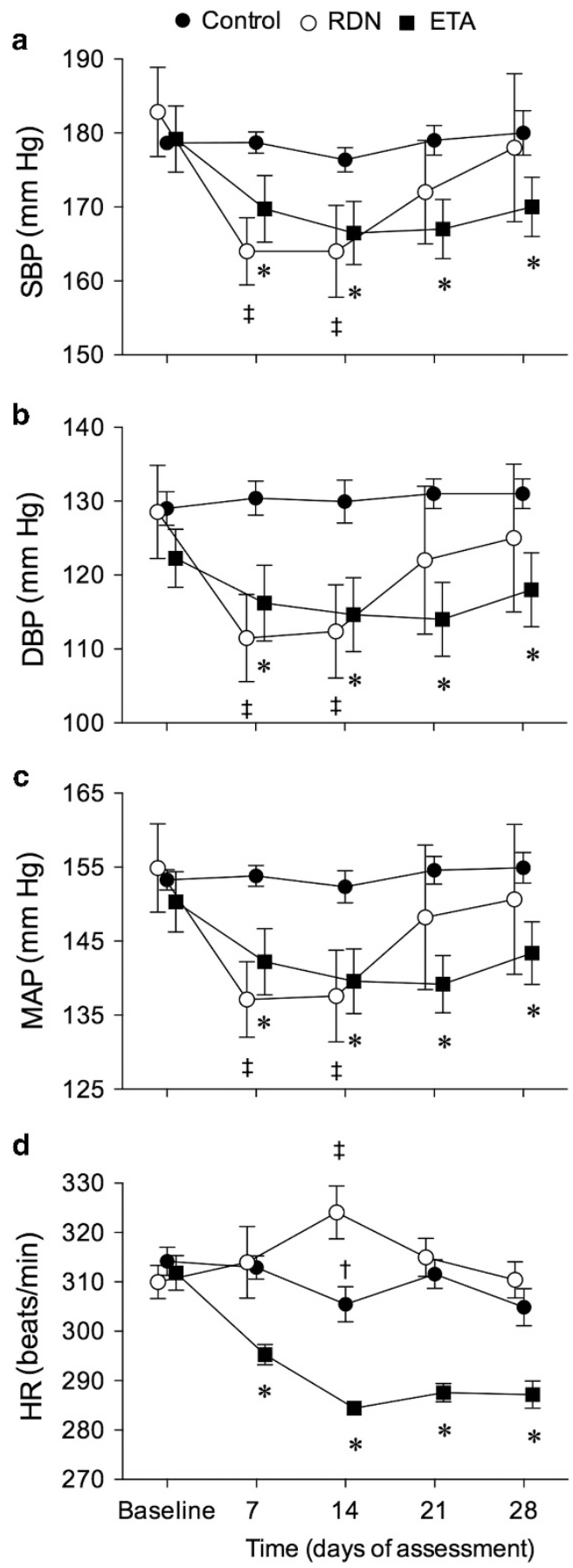

Figure 2 Effect of renal denervation and etamicastat treatment on (a) systolic blood pressure, (b) diastolic blood pressure, (c) mean arterial blood pressure and (d) heart rate. Values were determined to be significantly different from the corresponding baseline values by a repeated-measures analysis of variance followed by Dunnett's multiple comparison test ( ${ }^{\dagger} P<0.05$ for Control, $n=7 ;{ }^{\ddagger} P<0.05$ for renal denervation, $n=6$; $* P<0.05$ for etamicastat treatment, $n=6$ ). The data are shown as the mean \pm s.e.m.

surgery. NA and adrenaline levels returned to control levels on the final day of the assessment after targeted sympathetic ablation. Etamicastat treatment resulted in a sustained, $\approx 30 \%$ decrease in NA and adrenaline levels in the adrenal glands that was observed 7 and 28 days post intervention compared with the control rats. 


\section{7 days post-intervention}

a

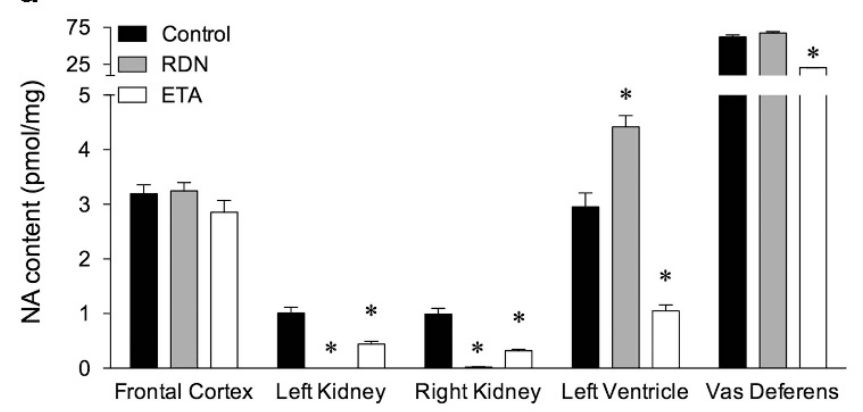

b

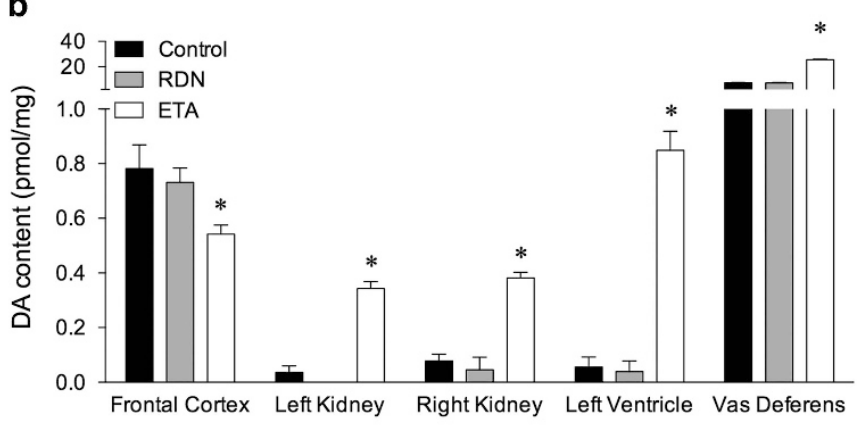

\section{8 days post-intervention}

c

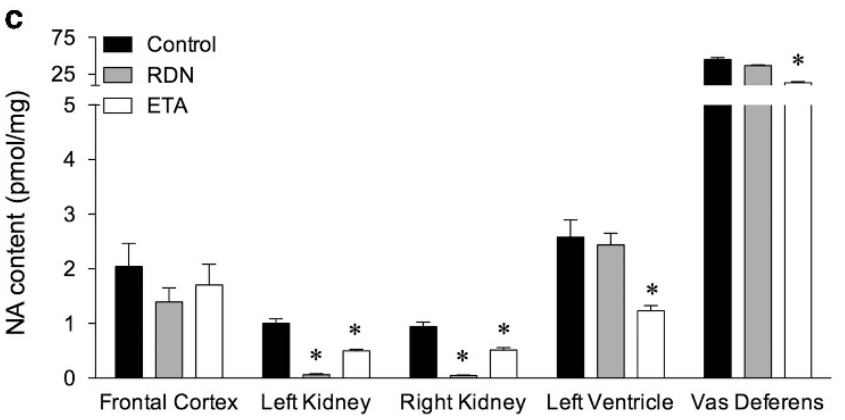

d

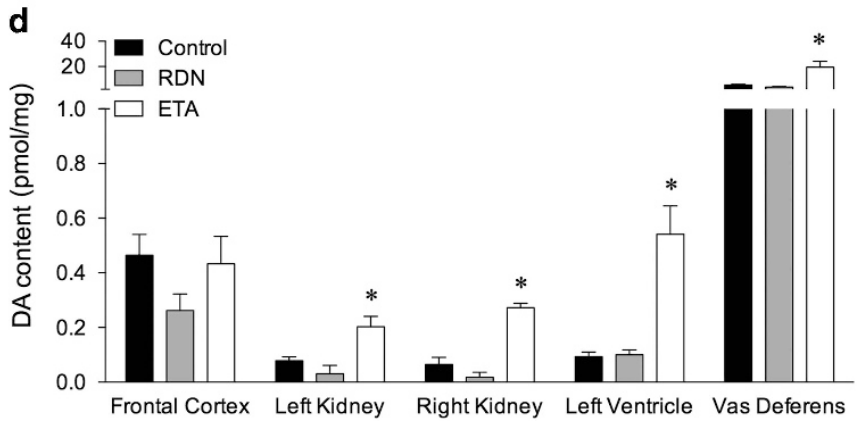

Figure 3 Effect of renal denervation $(n=5-6)$ and etamicastat treatment $(n=6)$ on (a and $\mathbf{c}$ ) noradrenaline and ( $\mathbf{b}$ and $\mathbf{d}$ ) dopamine levels in the frontal cortex, kidney (renal cortex), heart (left ventricle) and vas deferens 7 and 28 days post intervention. Values were determined to be significantly different from corresponding control values $(n=6-7)$ by a one-way analysis of variance followed by Dunnett's multiple comparison test $\left({ }^{*} P<0.05\right)$. The data are shown as the mean \pm s.e.m.

Urinary NA levels are shown in Figure 5. RDN had no effect on the urinary NA excretion. Conversely, etamicastat treatment resulted in an $\approx 80 \%$ decrease in 24 -h urinary NA levels at all time points of the protocol compared with the baseline levels.

\section{D $\beta H$ activity}

Tyramine can be oxidized to octopamine in a reaction that is catalyzed by $\mathrm{D} \beta \mathrm{H}$. $\mathrm{D} \beta \mathrm{H}$ activity can be defined based on the rate of formation of octopamine in rat adrenal gland homogenates. This assay was performed to demonstrate the target-specific effect of chronic etamicastat treatment on peripheral enzymatic $\mathrm{D} \beta \mathrm{H}$ activity at the end of the study. Figure 6 displays the D $\beta \mathrm{H}$ activity at the end of the protocol. The RDN surgery protocol did not alter adrenal $\mathrm{D} \beta \mathrm{H}$ activity $\left(46.2 \pm 6.4 \mathrm{ng} \mathrm{mg}^{-1}\right.$ protein per min) compared with control animals $\left(65.5 \pm 11.4 \mathrm{ng} \mathrm{mg}^{-1}\right.$ protein per $\left.\mathrm{min}\right)$. However, prolonged oral etamicastat treatment led to a significant decrease $(\approx 62 \%)$ in adrenal $\mathrm{D} \beta \mathrm{H}$ activity $\left(24.8 \pm 8.4 \mathrm{ng} \mathrm{mg}^{-1}\right.$ protein per min $)$ compared with control animals.

\section{DISCUSSION}

Renal sympathetic denervation has recently been introduced in the clinical setting for treatment-resistant hypertension. Although a longterm follow-up (36 months) confirms that reductions in BP are sustained, ${ }^{19}$ the placebo-control SYMPLICITY HTN-3 study found no significant effect of RDN on office or 24-hour ambulatory SBP. ${ }^{20}$ Moreover, patient selection constraints limit the use of these systems in the general therapy-resistant hypertensive population. ${ }^{21}$ Failure to achieve a complete circumferential denervation by using the
SYMPLICITY single-tip catheter has been proposed as a reason for the failure of this study to achieve its primary efficacy end point. The EnligHTN I was the first-in-human study, using a multielectrode ablation system, in patients with drug-resistant hypertension. ${ }^{14}$ Twelve months of data, together with a complete analysis of efficacy and safety information, including office, 24-hour ambulatory, and home BP measurements, are now available and continue to demonstrate the safety and efficacy of the EnligHTN ablation system in patients with drug-resistant hypertension. ${ }^{44}$ The EnligHTN I study was, however, an unblinded and single-arm study.

The present study aimed to determine the efficacy of RDN and $\mathrm{D} \beta \mathrm{H}$ inhibition via a chronic etamicastat treatment in the reduction of peripheral sympathetic activity and high BP in SHR, which are a rat model of genetic essential hypertension. The data presented here clearly demonstrate that in SHR, whereas RDN surgery, which caused a decrease in renal NA levels by more than $95 \%$ throughout the assessment period (28 days), resulted in only a transitory decrease in high $\mathrm{BP}$, the reduction in peripheral sympathetic activity produced by prolonged treatment with etamicastat resulted in a sustained amelioration of high BP over the entire assessment period. A decrease in NA release as a result of $\mathrm{D} \beta \mathrm{H}$ inhibition gradually slows down the sympathetic drive and thus leads to an indirect decrease in the activation of $\alpha$ - and $\beta$-adrenoceptors. ${ }^{24}$ Indeed, etamicastat treatment resulted in a $\approx 50 \%$ decrease in NA content and a marked increase in DA content in peripheral tissues with sympathetic innervation. Increased DA availability ${ }^{24,25}$ may result in additional benefits, as DA improves renal function by causing renal vasodilatation and by inducing diuresis and natriuresis. ${ }^{26-28}$ Nonetheless, the renal effect of 


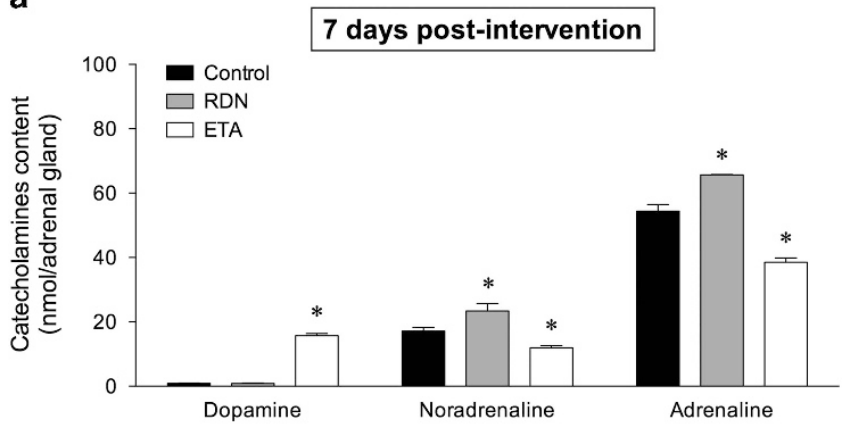

b

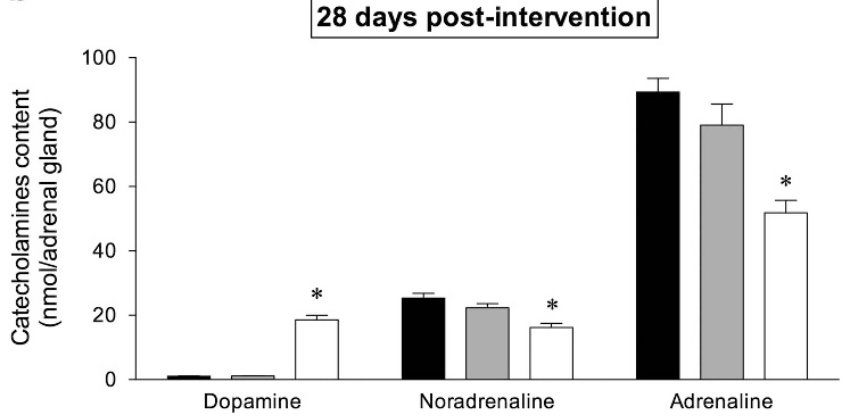

Figure 4 Effect of renal denervation $(n=5)$ and etamicastat treatment $(n=6)$ on catecholamine (dopamine, noradrenaline and adrenaline) content in the adrenal glands 7 and 28 days post intervention. Values were determined to be significantly different from corresponding control values $(n=6)$ by a one-way analysis of variance followed by Dunnett's multiple comparison test $\left({ }^{*} P<0.05\right)$. The data are shown as the mean \pm s.e.m.

DA is impaired in SHR because of defects in renal transduction of the DA signal. ${ }^{45}$

SHR represent an experimental model of hypertension; many characteristics of SHR resemble those found in essential hypertension in humans. Hypertension in SHR is a heterogeneous, multifactorial disorder. ${ }^{46,47}$ In agreement with previous reports, ${ }^{48-50}$ in this study, we showed that specific renal sympathetic nervous system ablation causes a transitory decrease in BP in SHR. Transient increases in NA levels were observed 7 days post RDN in the left ventricle of the heart and in the adrenal glands, which resulted in an increase, albeit not significant, in urinary NA levels (7 days), before returning to values similar to those in control SHR by the end of the assessment period. Although $\mathrm{RDN}$ has a target-specific effect on renal sympathetic nerves, ${ }^{51}$ ablation of renal sympathetic nervous system efferents and afferents has been shown to induce a transient increase in peripheral sympathetic drive, which can trigger compensatory systemic factors and mechanisms that cause a gradual return to high BP. ${ }^{46,52}$ Experimental evidence suggests that after denervation, a return of functional activity precedes the complete regrowth of nerve fibers. For example, the functional activity of the rat heart has been shown to approach control levels two weeks after sympathectomy, when myocardial catecholamine stores were still $80 \%$ depleted. ${ }^{53}$ Moreover, in the chronically denervated rat kidney, supersensitivity increases renal responsiveness to NA. ${ }^{54,55}$

Etamicastat treatment produced a significant reduction in urinary NA levels $(\approx 80 \%)$, whereas $\mathrm{RDN}$ failed to significantly alter urinary NA levels. However, both treatments reduced kidney tissue levels of $\mathrm{NA}$; this effect was more marked in the RDN group. Total chronic denervation of one kidney has been shown to have no effect on the rate of excretion of endogenous NA, and the NA that is subsequently

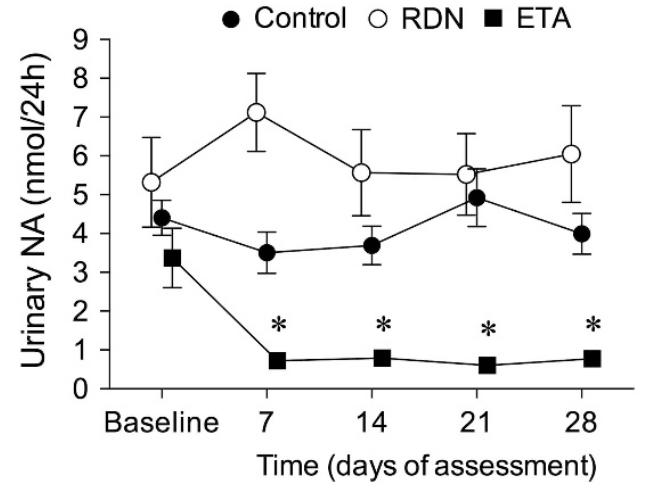

Figure 5 Effect of renal denervation $(n=6)$ and etamicastat treatment $(n=6)$ on urinary noradrenaline excretion. Values were determined to be significantly different from the corresponding baseline values by a repeatedmeasures analysis of variance followed by Dunnett's multiple comparison test ( ${ }^{*} P<0.05$ for etamicastat treatment; control group, $n=7$ ). The data are shown as the mean \pm s.e.m.

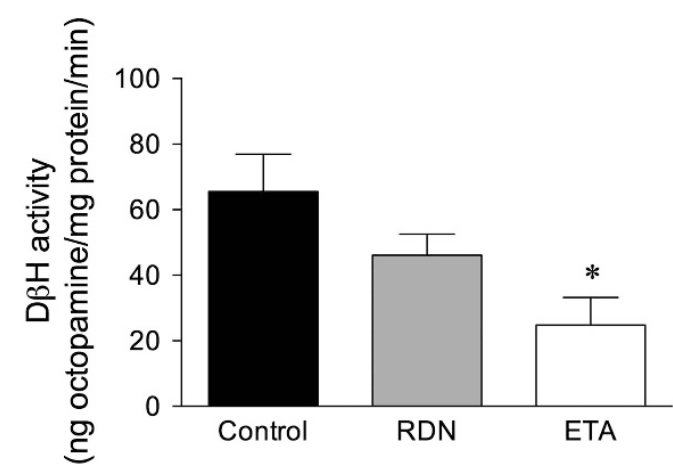

Figure 6 Effect of renal denervation $(n=6)$ and etamicastat treatment $(n=6)$ on the inhibition of dopamine $\beta$-hydroxylase activity in rat adrenal glands on the final day of the protocol. Values were determined to be significantly different from the corresponding control $(n=7)$ values by using a one-way analysis of variance followed by Dunnett's multiple comparison test $\left({ }^{*} P<0.05\right)$. The data are shown as the mean \pm s.e.m.

excreted in the urine appears to be derived solely from the circulating catecholamines. ${ }^{56,57}$ Indeed, etamicastat treatment resulted in a general reduction in peripheral noradrenergic drive, as evidenced by the reductions in NA levels observed in the heart, vas deferens and adrenal gland. Given that NA outputs correlate positively with creatinine clearance, ${ }^{58,59}$ the reduction in urinary NA levels in etamicastat-treated animals may be attributed to a reduction in peripheral sympathetic drive.

Chronic etamicastat treatment resulted in a sustained reduction in BP and in a small, but significant, decrease in pulse pressure in SHR. The effects of etamicastat on BP may be attributed to a reduced activation of both peripheral $\alpha$ - and $\beta$-adrenoceptors. ${ }^{26}$ The observed decrease in HR values may be accounted for by the diminished activation of $\beta$-adrenoceptors; $\beta$-blockers are known to decrease pulse pressure through negative inotropic and chronotropic actions. ${ }^{60}$ The effect of etamicastat treatment on HR that was observed in this study was not observed in prior studies. ${ }^{36,37}$ Nonetheless, It should be noted that previous studies evaluated the effects of etamicastat on BP and HR in SHR after a single dose, with measurements made by monitoring telemetry $\operatorname{signals}^{36}$ or by using the tail-cuff plethysmography method. $^{37}$ Although similar BP outcomes were obtained in all of 
these studies, differences in the methodology and in the study protocol may explain the differences observed in the pulse pressure.

In conclusion, these results support the use of peripheral $\mathrm{D} \beta \mathrm{H}$ inhibitors as a promising approach for the treatment of cardiovascular disorders such as hypertension and chronic heart failure, where a reduction in NA levels may be of therapeutic benefit.

\section{CONFLICT OF INTEREST}

NMP, BI, EM, LCW and PSS are/were employees of BIAL-Portela \& Ca, S.A. (the sponsor of the study) at the time of the study.

\section{ACKNOWLEDGEMENTS}

This work was supported by BIAL-Portela \& Ca, S.A. We thank João Ferreira and Ana I. Loureiro for their technical assistance.

1 Mancia G, Fagard R, Narkiewicz K, Redon J, Zanchetti A, Bohm M, Christiaens T, Cifkova R, De Backer G, Dominiczak A, Galderisi M, Grobbee DE, Jaarsma T, Kirchhof P, Kjeldsen SE, Laurent S, Manolis AJ, Nilsson PM, Ruilope LM, Schmieder RE, Sirnes PA, Sleight P, Viigimaa M, Waeber B, Zannad F, Burnier M, Ambrosioni E, Caufield M, Coca A, Olsen MH, Tsioufis C, van de Borne P, Zamorano JL, Achenbach S, Baumgartner H, Bax JJ, Bueno H, Dean V, Deaton C, Erol C, Ferrari R, Hasdai D, Hoes AW, Knuuti J, Kolh P, Lancellotti P, Linhart A, Nihoyannopoulos P, Piepoli MF, Ponikowski P, Tamargo JL, Tendera M, Torbicki A, Wijns W, Windecker S, Clement DL, Gillebert TC, Rosei EA, Anker SD, Bauersachs J, Hitij JB, Caulfield M, De Buyzere M, De Geest S, Derumeaux GA, Erdine S, Farsang C, Funck-Brentano C, Gerc V, Germano G, Gielen S, Haller H, Jordan J, Kahan T, Komajda M, Lovic D, Mahrholdt H, Ostergren J, Parati G, Perk J, Polonia J, Popescu BA, Reiner Z, Ryden L, Sirenko Y, Stanton A, Struijker-Boudier H, Vlachopoulos C, Volpe M, Wood DA2013ESH/ESC Guidelines for the management of arterial hypertension: The Task Force for the management of arterial hypertension of the European Society of Hypertension (ESH) and of the European Society of Cardiology (ESC). Eur Heart J 2013; 34: 2159-2219.

2 Kearney PM, Whelton M, Reynolds K, Muntner P, Whelton PK, He J. Global burden of hypertension: analysis of worldwide data. Lancet 2005; 365: 217-223.

3 Nishikawa T, Omura M, Saito J, Matsuzawa Y. The possibility of resistant hypertension during the treatment of hypertensive patients. Hypertens Res 2013; 36: 924-929.

4 Calhoun DA, Jones D, Textor S, Goff DC, Murphy TP, Toto RD, White A, Cushman WC, White W, Sica D, Ferdinand K, Giles TD, Falkner B, Carey RM. Resistant hypertension: diagnosis, evaluation, and treatment. A scientific statement from the American Heart Association Professional Education Committee of the Council for High Blood Pressure Research. Hypertension 2008; 51: 1403-1419.

5 Grassi G. Sympathetic neural activity in hypertension and related diseases. Am J Hypertens 2010; 23: 1052-1060.

6 Grassi G, Seravalle G, Quarti-Trevano F. The 'neuroadrenergic hypothesis' in hypertension: current evidence. Exp Physiol 2010; 95: 581-586.

7 Esler M, Kaye D. Sympathetic nervous system activation in essential hypertension, cardiac failure and psychosomatic heart disease. J Cardiovasc Pharmacol 2000; 35: S1-S7.

8 Parati G, Esler M. The human sympathetic nervous system: its relevance in hypertension and heart failure. Eur Heart J 2012; 33: 1058-1066.

9 Grassi G, Bolla G, Quarti-Trevano F, Arenare F, Brambilla G, Mancia G. Sympathetic activation in congestive heart failure: reproducibility of neuroadrenergic markers. Eur Heart Fail 2008; 10: 1186-1191.

10 Lee CS, Tkacs NC. Current concepts of neurohormonal activation in heart failure: mediators and mechanisms. AACN Adv Crit Care 2008; 19: 364-385.

11 Mancia G, Grassi G, Giannattasio C, Seravalle G. Sympathetic activation in the pathogenesis of hypertension and progression of organ damage. Hypertension 1999; 34: 724-728.

12 Malpas SC. Sympathetic nervous system overactivity and its role in the development of cardiovascular disease. Physiol Rev 2010; 90: 513-557.

13 Krum H, Schlaich M, Whitbourn R, Sobotka PA, Sadowski J, Bartus K, Kapelak B, Walton A, Sievert H, Thambar S, Abraham WT, Esler M. Catheter-based renal sympathetic denervation for resistant hypertension: a multicentre safety and proof-ofprinciple cohort study. Lancet 2009; 373: 1275-1281.

14 Worthley SG, Tsioufis CP, Worthley MI, Sinhal A, Chew DP, Meredith IT, Malaiapan Y, Papademetriou V. Safety and efficacy of a multi-electrode renal sympathetic denervation system in resistant hypertension: the EnligHTN I trial. Eur Heart J 2013; 34 2132-2140.

15 Cohen-Mazor M, Mathur P, Stanley JR, Mendelsohn FO, Lee H, Baird R, Zani BG, Markham PM, Rocha-Singh K. Evaluation of renal nerve morphological changes and norepinephrine levels following treatment with novel bipolar radiofrequency delivery systems in a porcine model. J Hypertens 2014; 32: 1678-1691.

16 Mabin T, Sapoval M, Cabane V, Stemmett J, Iyer M. First experience with endovascular ultrasound renal denervation for the treatment of resistant hypertension. Eurolntervention 2012; 8: 57-61.
17 Ormiston JA, Watson T, van Pelt N, Stewart R, Haworth P, Stewart JT, Webster MW. First-in-human use of the OneShot ${ }^{\mathrm{TM}}$ renal denervation system from Covidien. EuroIntervention 2013; 8: 1090-1094.

18 Mahfoud F, Luscher TF, Andersson B, Baumgartner I, Cifkova R, Dimario C, Doevendans P, Fagard R, Fajadet J, Komajda M, Lefevre T, Lotan C, Sievert H, Volpe M, Widimsky P, Wijns W, Williams B, Windecker S, Witkowski A, Zeller T, Bohm M. Expert consensus document from the European Society of Cardiology on catheter-based renal denervation. Eur Heart J 2013; 34: 2149-2157.

19 Esler MD, Bohm M, Sievert H, Rump CL, Schmieder RE, Krum H, Mahfoud F, Schlaich MP. Catheter-based renal denervation for treatment of patients with treatmentresistant hypertension: 36 month results from the SYMPLICITY HTN-2 randomized clinical trial. Eur Heart J 2014; 35: 1752-1759.

20 Bhatt DL, Kandzari DE, O'Neill WW, D'Agostino R, Flack JM, Katzen BT, Leon MB, Liu M, Mauri L, Negoita M, Cohen SA, Oparil S, Rocha-Singh K, Townsend RR, Bakris GL. A controlled trial of renal denervation for resistant hypertension. N Eng/ J Med 2014; 370: 1393-1401.

21 Hayek SS, Abdou MH, Demoss BD, Legaspi JM, Veledar E, Deka A, Krishnan SK, Wilmot KA, Patel AD, Kumar VR, Devireddy CM. Prevalence of resistant hypertension and eligibility for catheter-based renal denervation in hypertensive outpatients. $A m ~ J$ Hypertens 2013; 26: 1452-1458.

22 Stanley WC, Li B, Bonhaus DW, Johnson LG, Lee K, Porter S, Walker K, Martinez G, Eglen RM, Whiting RL, Hegde SS. Catecholamine modulatory effects of nepicastat (RS-25560-197), a novel, potent and selective inhibitor of dopamine-beta-hydroxylase. Br J Pharmacol 1997; 121: 1803-1809.

23 Hegde SS, Friday KF. Dopamine-beta-hydroxylase inhibition: a novel sympathomodulatory approach for the treatment of congestive heart failure. Curr Pharm Des 1998; 4: 469-479.

24 Soares-da-Silva P. Evidence for a non-precursor dopamine pool in noradrenergic neurones of the dog mesenteric artery. Naunyn Schmiedebergs Arch Pharmacol 1986; 333: 219-223.

25 Soares-da-Silva P. A comparison between the pattern of dopamine and noradrenaline release from sympathetic neurones of the dog mesenteric artery. Br J Pharmacol 1987; 90: 91-98.

26 Gomes P, Soares-da-Silva P. Dopamine. In: Baden M (ed), Cardiovascular Hormone Systems: From Molecular Mechanisms to Novel Therapeutics. Wiley-VCH: Weinheim. 2008, 251-293.

27 Jose PA, Eisner GM, Felder RA. Role of dopamine receptors in the kidney in the regulation of blood pressure. Curr Opin Nephrol Hypertens 2002; 11: 87-92.

28 Jose PA, Soares-da-Silva P, Eisner GM, Felder RA. Dopamine and G protein-coupled receptor kinase 4 in the kidney: role in blood pressure regulation. Biochim Biophys Acta 2010; 1802: 1259-1267.

29 Ishii Y, Fujii Y, Mimura C, Umezawa H. Pharmacological action of FD-008, a new dopamine beta-hydroxylase inhibitor. I. Effects on blood pressure in rats and dogs. Arzneimittelforschung 1975; 25: 55-59.

30 Kruse LI, Kaiser C, DeWolf WE Jr., Frazee JS, Ross ST, Wawro J, Wise M, Flaim KE, Sawyer JL, Erickson RW, Ezekiel M, Ohlstein EH, Berkowitz BA. Multisubstrate inhibitors of dopamine beta-hydroxylase. 2. Structure-activity relationships at the phenethylamine binding site. J Med Chem 1987; 30: 486-494.

31 Ohlstein EH, Kruse LI, Ezekiel M, Sherman SS, Erickson R, DeWolf WE Jr, Berkowitz BA. Cardiovascular effects of a new potent dopamine beta-hydroxylase inhibitor in spontaneously hypertensive rats. J Pharmacol Exp Ther 1987; 241: 554-559.

32 Beliaev A, Ferreira H, Learmonth DL, Soares-da-Silva P. Dopamine beta-monooxygenase: mechanism, substrates and inhibitors. Curr Enzyme Inh 2009; 5: 27-43.

33 Kruse LI, Kaiser C, DeWolf WE Jr., Frazee JS, Erickson RW, Ezekiel M, Ohlstein EH, Ruffolo RR Jr, Berkowitz BA. Substituted 1-benzylimidazole-2-thiols as potent and orally active inhibitors of dopamine beta-hydroxylase. J Med Chem 1986; 29. 887-889.

34 Beliaev A, Learmonth DA, Soares-da-Silva P. Synthesis and biological evaluation of novel, peripherally selective chromanyl imidazolethione-based inhibitors of dopamine beta-hydroxylase. J Med Chem 2006; 49: 1191-1197.

35 Bonifácio MJ, Igreja B, Wright L, Soares-da-Silva P. Kinetic studies on the inhibition of dopamine-ß-hydroxylase by BIA 5-453. PA2 online 2009; 7: 050P.

36 Igreja B, Pires NM, Bonifácio MJ, Loureiro Al, Fernandes-Lopes C, Wright LC, Soaresda-Silva P. Blood pressure-decreasing effect of etamicastat alone and in combination with antihypertensive drugs in the spontaneously hypertensive rat. Hypertens Res 2015; 38: 30-38.

37 Igreja B, Wright L, Soares-da-Silva P. Sustained antihypertensive effects of a selective peripheral dopamine-ß-hydroxylase inhibitor. Hypertension 2007; 50: E133.

38 Almeida L, Nunes T, Costa R, Rocha JF, Vaz-da-Silva M, Soares-da-Silva P. Etamicastat, a novel dopamine beta-hydroxylase inhibitor: tolerability, pharmacokinetics, and pharmacodynamics in patients with hypertension. Clin Ther 2013; 35: 1983-1996.

39 Jacob F, Ariza P, Osborn JW. Renal denervation chronically lowers arterial pressure independent of dietary sodium intake in normal rats. Am J Physiol Heart Circ Physio 2003; 284: H2302-H2310.

40 Loureiro Al, Fernandes-Lopes C, Bonifacio MJ, Wright LC, Soares-da-Silva P. Nacetylation of etamicastat, a reversible dopamine-beta-hydroxylase inhibitor. Drug Metab Dispos 2013; 41: 2081-2086.

41 Soares-da-Silva P, Pestana M, Vieira-Coelho MA, Fernandes MH, Albino-Teixeira A. Assessment of renal dopaminergic system activity in the nitric oxide-deprived hypertensive rat model. Br J Pharmacol 1995; 114: 1403-1413.

42 Nagatsu T, Udenfriend S. Photometric assay of dopamine-beta-hydroxylase activity in human blood. Clin Chem 1972; 18: 980-983. 
43 Rocha JF, Vaz-da-Silva M, Nunes T, Igreja B, Loureiro Al, Bonifácio MJ, Wright LC Falcão A, Almeida L, Soares-da-Silva P. Single-dose tolerability, pharmacokinetics, and pharmacodynamics of etamicastat (BIA 5-453), a new dopamine B-hydroxylase inhibitor, in healthy subjects. J Clin Pharmacol 2012; 52: 156-170.

44 Papademetriou V, Tsioufis CP, Sinhal A, Chew DP, Meredith IT, Malaiapan Y, Worthley MI, Worthley SG. Catheter-based renal denervation for resistant hypertension: 12-month results of the EnligHTN I first-in-human study using a multielectrode ablation system. Hypertension 2014; 64: 565-572.

45 Jose PA, Eisner GM, Drago J, Carey RM, Felder RA. Dopamine receptor signaling defects in spontaneous hypertension. Am J Hypertens 1996; 9: 400-405.

46 Doggrell SA, Brown L. Rat models of hypertension, cardiac hypertrophy and failure. Cardiovasc Res 1998; 39: 89-105.

47 Du CQ, Yang L, Yang J, Han J, Hu XS, Wu T, Hu SJ. Inhibition of farnesyl pyrophosphate synthase prevents norepinephrine-induced fibrotic responses in vascular smooth muscle cells from spontaneously hypertensive rats. Hypertens Res 2014; 37: 26-34.

48 Winternitz SR, Katholi RE, Oparil S. Role of the renal sympathetic nerves in the development and maintenance of hypertension in the spontaneously hypertensive rat. J Clin Invest 1980; 66: 971-978.

49 Jiang W, Tan L, Guo Y, Li X, Tang X, Yang K. Effect of renal denervation procedure on left ventricular hypertrophy of hypertensive rats and its mechanisms. Acta Cir Bras 2012; 27: 815-820.

50 Kline RL, Stuart PJ, Mercer PF. Effect of renal denervation on arterial pressure and renal norepinephrine concentration in Wistar-Kyoto and spontaneously hypertensive rats. Can J Physiol Pharmacol 1980; 58: 1384-1388.
51 Foss JD, Fink GD, Osborn JW. Reversal of genetic salt-sensitive hypertension by targeted sympathetic ablation. Hypertension 2013; 61: 806-811.

52 Guyton AC. Blood pressure control-special role of the kidneys and body fluids. Science 1991; 252: 1813-1816.

53 Nadeau RA, de Champlain J, Tremblay GM. Supersensitivity of the isolated rat heart after chemical sympathectomy with 6-hydroxydopamine. Can J Physiol Pharmacol 1971; 49: 36-44.

54 Kline RL, Mercer PF. Functional reinnervation and development of supersensitivity to NE after renal denervation in rats. Am J Physiol 1980; 238: R353-R358.

55 Krayacich J, Kline RL, Mercer PF. Supersensitivity to NE alters renal function of chronically denervated rat kidneys. Am J Physiol 1987; 252: F856-F864.

56 Overy HR, Pfister R, Chidsey CA. Studies on the renal excretion of norepinephrine. $J$ Clin Invest 1967; 46: 482-489.

57 Eisenhofer G, Kopin IJ, Goldstein DS. Catecholamine metabolism: a contemporary view with implications for physiology and medicine. Pharmacol Rev 2004; 56: 331-349.

58 Roberts NB, Dutton J, McClelland P, Bone JM. Urinary catecholamine excretion in relation to renal function. Ann Clin Biochem 1999; 36: 587-591.

59 Silva P, Landsberg L, Besarab A. Excretion and metabolism of catecholamines by the isolated perfused rat kidney. J Clin Invest 1979; 64: 850-857.

60 Rosendorff C, Black HR, Cannon CP, Gersh BJ, Gore J, Izzo JLJ, Kaplan NM, O'Connor CM, O'Gara PT, Oparil S. Treatment of hypertension in the prevention and management of ischemic heart disease: a scientific statement from the American Heart Association Council for High Blood Pressure Research and the Councils on Clinical Cardiology and Epidemiology and Prevention. Circulation 2007; 115: 2761-2788. 